\title{
Low Zip 4 gene expression levels in RPMI - 8226 and ARH - 77 cell lines support the possible role of zip 4 transporter protein in plasma cell tumorogenesis
}

\author{
RPMI-8226 ve ARH-77 hücre hatlarında düşük Zip 4 gen ekspresyon düzeyi \\ bulgusu plazma hücrelerinden köken alan tümörlerin gelişiminde Zip 4 taşıyıcı \\ proteininin olası rolünü desteklemektedir
}

Zehra Dilşad Çoban, Deniz Torun, Ferit Avcu, Ali Uğur Ural, Erhan Parıltay, Salih Kozan, Şefik Güran*

Department of Medical Biology (Z. D. Çoban, MD, Prof. Ş. Güran, MD), Department of Genetics (D. Torun, MD, E. Pariltay, MD, S. Kozan, MD), Department of Hematology (Assoc. Prof. F. Avcu, Prof. A. U. Ural, MD), Gülhane Military Medical Academy, TR-06010 Ankara

\begin{abstract}
Aim. Multiple myeloma and plasma cell leukemia are cancers of plasma cells. Multiple myeloma rarely transforms to plasma cell leukemia during the progression period. Zinc as a chemical element modulates proliferation and differentiation of cells by affecting several growth factors. Zip 4 modifies zinc metabolism in a cell as a transporter protein. While high Zip 4 gene expression was found in pancreas and hepatocellular carcinoma, low Zip 4 gene expression was observed in prostate carcinoma. Methods. Here, Zip 4 expression levels were studied in RPMI - 8226 and ARH - 77 cell lines as examples of multiple myeloma and plasma cell leukemia, respectively. Results. We found lower Zip 4 gene expression levels in both cell lines than that of the normal control (0,000157 in RPMI - 8226, 0,000227 in ARH - 77 cell lines and 1 in normal control) The findings were statistically significant $(\mathrm{P}<0.05)$. The expression levels of Zip 4 gene in both cell lines were approximately similar. No statistical significance was found between the expression levels of Zip 4 in both cell lines $(\mathrm{P}=0.547)$. Conclusion. The results of this study support the possible role of Zip 4 gene expression in plasma cell dyscrasias. The similar result of Zip 4 gene expression level in both cell lines may show that Zip 4 has no role in the transformation of multiple myeloma to plasma cell leukemia.
\end{abstract}

Keywords: Zip 4 gene, gene expression, multiple myeloma, plasma cell leukemia

\section{Özet}

Amaç. Mltipl myelom ve plazma hücreli lösemi, plazma hücresinden köken alan kanserlerdir. Hastalığın ileri evresinde multipl myelom nadiren plazma hücreli lösemi formuna döner. Kimyasal bir element olarak çinko farklı büyüme faktörleri üzerinden memeli hücrelerinde çoğalma ve farklılaşmayı düzenler. Taşıyıcı bir protein olarak Zip 4 ise hücrede çinko metabolizmasında aktif rol alır. Pankreas ve karaciğer kanserlerinde artmış Zip 4 gen ekspresyonu bulunurken, prostat kanserinde düşük Zip 4 gen ekspresyonu tanımlanmaktadır. Yöntemler. Bu çalışmada, sırası ile multipl myelom ve plazma hücreli lösemilere örnek olabilecek RPMI - 8226 ve ARH - 77 hücre hatlarında Zip 4 gen ekspresyon düzeyleri bakılmıştır. Bulgular. Her iki hücre hattında Zip 4 gen ekspresyon düzeyi normale göre daha düşüktür (RPMI - 8226 hücre hattında 0,000157 ve ARH 77 hücre hattında 0,000227). Elde edilen veriler istatistiksel olarak anlamlıdır $(\mathrm{P}<0,05)$. Her iki hücre hattında Zip 4 gen ekspresyon düzeyleri birbirine çok yakın olarak bulunmuştur. Aralarında istatistiksel olarak anlamlı bir fark da bulunmamıştır $(P=0,547)$. Sonuç. Sonuçlar plazma hücre diskrazilerinde Zip 4 gen ekspresyonunun olası rolünü destekler niteliktedir. Her iki hücre hattında birbirine yakın bulunan Zip 4 gen ekpresyon düzeyi Zip 4'ün multipl myelomanın plazma hücreli lösemiye dönüşmesinde rolü olmadığını ortaya koymaktadır.

Anahtar sözcükler: Zip 4 geni, gen ekspresyonu, multipl myelom, plazma hücreli lösemi 
Geliş tarihi/Received: August 24, 2012; Kabul tarihi/Accepted: January 21, 2013

*Corresponding author:

Dr. Şefik Güran, Tıbbi Biyoloji Anabilim Dalı, Gülhane Askeri Tıp Akademisi, TR-06010 Ankara. E-mail: sefguran@yahoo.com

\section{Introduction}

Multiple myeloma (MM) and plasma cell leukemia (PCL) are the cancers of plasma cells [1]. PCL may be primary (de novo), or secondary. Secondary PCL generally evolves from MM. PCL in secondary cases may be accepted as a terminal phase of MM. Two cell lines, RPMI - 8226 and ARH - 77 are the examples of MM and PCL respectively [2, 3]. As known, zinc $(\mathrm{Zn})$ is essential for the structures and functions of proteins and enzymes in mammalian cells [4]. It modulates the proliferation and differentiation of the cells by affecting several growth factors in signaling cascades [5]. Recently, Zn transporters have been found to play roles in carcinogenesis. Zip 4 transporter protein as a member of Zrt Irt - like protein (Zip) super family modifies zinc metabolism in the mammalian cells [6]. High Zip 4 gene expression levels were reported in pancreas and hepatocellular cancers [7, 8]. Low Zip 4 gene expression level was found in prostate cancer cell lines [9].

We studied the expression levels of Zip 4 gene on RPMI - 8226 (originated from MM) and ARH - 77 (originated from PCL) cell lines. Mononuclear cells (MNCs) obtained from peripheral blood were used as normal control.

\section{Materials and methods}

Cell culture and RNA isolation: In this study, MM-RPMI - 8226 and PCL-ARH - 77 cell lines were used. MNCs were used as normal control. RPMI - 8226 (ATCC No: CCL 155) and ARH - 77 (ATCC No: CRL - 1621) cell lines were obtained from American Tissue and Cell Culture (ATCC, LGC Standards GmbH Mercatorstr. 5146485 Wesel Germany.) MNCs were isolated from peripheral blood by using Ficoll gradient [10]. The cell lines were cultured in a standard protocol [11]. In the isolation of total RNAs from the cell lines and MNCs, a RNA isolation kit was used with the manufacturer's protocol (NucleoSpin RNA II, Macherey - Nagel). The integrity of RNA was verified following electrophoresis in $1 \%$ agarose gel with ethidium bromide staining.

Real-time PCR analyses: c DNA samples were obtained from total RNA's by using c DNA synthesis kit (RevertAid cDNA Synthesis Kit, Fermentas). For the gene expression profiles, real-time PCR (RT - PCR) analyses (Roche Applied Science: LightCycler ${ }^{\circledR} 480$ System) was performed. SYBR Green (Appliedbiosystems) was used for detection. A standard protocol was used as previously described in RT - PCR analyses [7]. In our experiments, the following gene-specific primers were used: Zip $4 \mathrm{~m}$ RNA [sense 5' AAGCACTGCTGCTGAACCTGGCCT $\quad 3^{\prime} ; \quad$ antisense $5^{\prime}$ GATGTCATCCTCGTACAGGGACAGCAGC $3^{\prime}$ ]. GAPDH m RNA [sense $5^{\prime}$ ACATCATCCCTGCCTCTACTGG 3'; antisense 5' TCCGACGCCTGCTTCACC 3'] [7].

Each sample analyzed in triplicate. RT - PCR efficiency in each condition was visualized by serial dilution of c DNA template. The melting-curve data were collected in each RT PCR analyses to confirm PCR specificity. GAPDH primers were used for sample variation in internal control. The amount of RT - PCR product was measured by threshold cycle $(\mathrm{Ct})$ value. The levels of Zip $4 \mathrm{~m}$ RNAs were normalized with the levels of GAPDH mRNAs. In normalization procedure, the following equation was used: fold-change $=2^{\text {(Ct }}$ Gene - Ct GAPDH) $[7,12]$.

Statistical analyses: Three groups of Zip 4 gene m RNA expression results (from two cell lines and control cells) were statistically analyzed by using "analysis of variance ANOVA test". For a comparison procedure, Tukey-Kramer method was used to find out the significantly different group in our series. 


\section{Results}

In RT-PCR analyses, the relative expression values of Zip 4 mRNA levels of both cell lines in accordance with MNCs were obtained (Figure 1). The relative value of Zip $4 \mathrm{~m}$ RNA expressions were 0,000157 in RPMI - 8226 and 0,000227 in ARH - 77 cell lines (Figure 2). Low levels of Zip 4 m RNAs were found in two cell lines in comparison with normal control (Figure 1). The inhibition of Zip $4 \mathrm{~m}$ RNA expression in both cell lines was statistically significant $(\mathrm{P}<0.05)$. These results may represent the down regulation of Zip 4 gene expression in MM and PCL.

As seen in figure 2, the expression levels of Zip 4 gene in both cell lines were approximately similar. By using the same methodology, a comparison of the Zip $4 \mathrm{~m}$ RNA levels between RPMI - 8226 and in ARH - 77 cell lines was done. According to these results, no statistical significance was observed among the Zip $4 \mathrm{~m}$ RNA levels in two cell lines $(\mathrm{P}=0.547)$ (Table 1$)$.

Table 1. ANOVA statistical results in three groups (normal control MNCs and two cell lines) with correction by Tukey-Kramer method.

\begin{tabular}{lll}
\hline & Significance (p value) & Results \\
\hline RPMI-8226 & 0,000 & Different \\
ARH-77 & 0,000 & Different \\
\hline MNC (Normal control) & 0,000 & Different \\
ARH-77 & 0,547 & Similar \\
\hline MNC (Normal control) & 0,000 & Different \\
RPMI-8226 & 0,547 & Similar \\
\hline
\end{tabular}

\section{Discussion}

RPMI - 8226 is a cell line obtained from MM tumor cells. ARH - 77 is a cell line obtained from PCL tumor cells. As known, these two cancers are originated from plasma cells. In clinical presentation, PCL is more aggressive than MM. The clinical features of PCL generally represent the common findings of acute leukemia and MM together [1-3].

Enhanced expression of the Zip 4 gene is found in many different cancers including pancreas and hepatocellular cancers [7, 8]. Zip 4 transporter protein can repress apoptosis and enhance cell-cycle and cell migration by using different pathways. The regulatory roles of Zip 4 transporter proteins have been reported in especially Wnt/ $\beta$-catenin, Notch, PI3/Kinase-AKT/mTOR and Hedgehog signaling pathways. So, it can effect on cancer growth and metastasis in a mammalian cell. Over expression of Zip 4 gene is associated with significantly increased expression of Neuropilin - 1 protein (NRP-1), vascular endothelial growth factor (VEGF) and type IV collagenases like matrix metalloproteinase - 2 (MMP - 2) and matrix metallopeptidase 9 (MMP - 9) in pancreatic cancers. So, overexpression of Zip 4 in pancreatic cancers with these factors support that Zip 4 has an important role in tumor development of pancreatic cells [13-15].

Recently, lower expression levels of Zip 4 gene were found in prostate carcinoma by Chen et al. [9]. Prostate carcinoma is the sole example to be associated with low Zip $4 \mathrm{~m}$ RNA expression levels among different types of cancers in the literature. Significantly lower Zip $4 \mathrm{~m}$ RNA expression levels were observed in our series like in prostate carcinoma (Figure 1 and 2). The inhibition of Zip 4 m RNA levels in both cancer cell lines originated from plasma cells supports the possible role of Zip 4 protein in tumor progression from plasma cells. There may be an unknown mechanism which affects the Zip $4 \mathrm{~m}$ RNA expression in plasma cell tumors. Zip 4 protein may have a tumor suppressor effect on plasma cells hence we found lower expression levels in plasma cell dyscrasias. 
In practice, PCL can be accepted as an aggressive form of MM [3, 17]. So, the levels of Zip 4 gene m RNA expression in these two cell lines may represent the possible role of Zip 4 protein in the transformation of MM to PCL. Also, such a kind of finding may be used as a prognostic marker in MM cases [9, 16, 17]. The expression levels of Zip 4 gene in MM and PCL originated cell lines were approximately similar in our series (Figure 2). According to our results, we may accept that Zip 4 protein has no role in the transformation of MM to PCL.

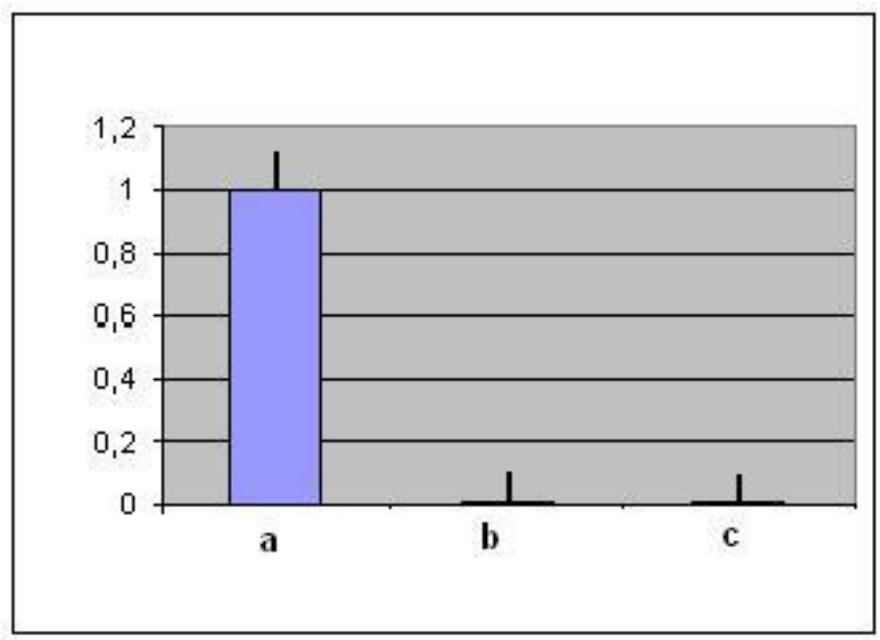

Figure 1. The relative Zip $4 \mathrm{~m}$ RNA levels of two cell lines in accordance with MNCs, (a) MNCs as control, (b) RPMI - 8226 cell line, (c) ARH - 77 cell line.

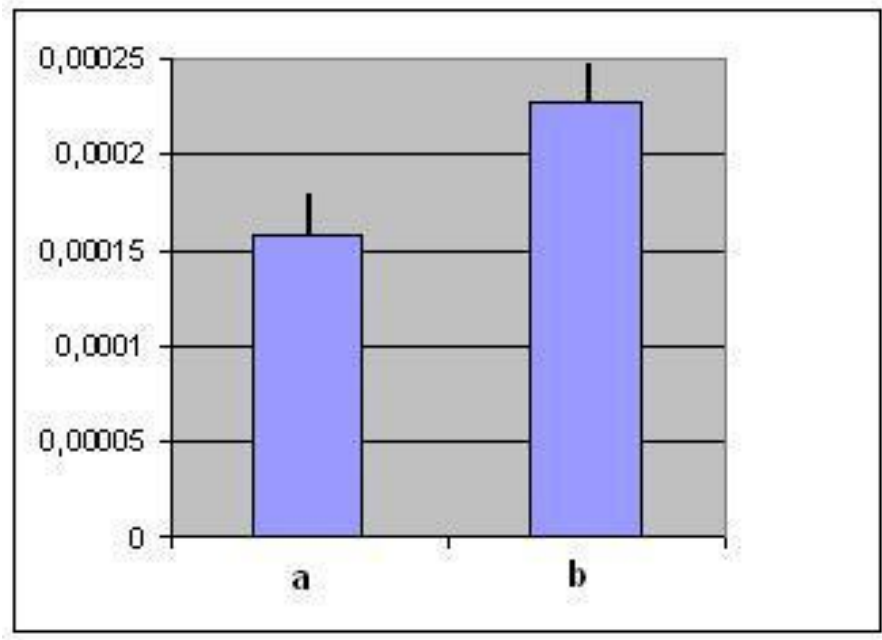

Figure 2. The relative Zip $4 \mathrm{~m}$ RNA levels of two cell lines (a) RPMI - 8226 cell line, (b) ARH - 77 cell line.

\section{References}

1. Raab MS, Podar K, Breitkreutz I, Richardson PG, Anderson KC. Multiple myeloma. Lancet 2009; 374: 324-39.

2. Lorsbach RB, Hsi ED, Dogan A, Fend F. Plasma cell myeloma and related neoplasms. Am J Clin Pathol 2011; 136: 168-82.

3. Albarracin F, Fonseca R. Plasma cell leukemia. Blood Rev 2011; 25: 107-12.

4. Berg JM, Shi Y. The galvanization of biology: A growing appreciation for the roles of zinc. Science 1996; 271: 1081-5.

5. Haase H, Rink L. Functional Significance of Zinc-Related Signaling Pathways in Immune Cells. Annu Rev Nutr 2009; 29: 133-52. 
6. Kambe T, Weaver BP, Andrews GK. The genetics of essential metal homeostasis during development. Genesis 2008; 46: 214-28.

7. Weaver BP, Zhang Y, Hiscox S, Guo GL, Apte U, Taylor KM, Sheline CT, Wang L, Andrews GK. Zip4 (Slc39a4) expression is activated in hepatocellular carcinomas and functions to repress apoptosis, enhance cell cycle and increase migration. PLoS One 2010; 5.

8. Zhang Y, Bharadwaj U, Logsdon CD, Chen C, Yao Q, Li M. ZIP4 regulates pancreatic cancer cell growth by activating IL-6/STAT3 pathway through zinc finger transcription factor CREB. Clin Cancer Res 2010; 16: 1423-30.

9. Chen QG, Zhang Z, Yang Q, Shan GY, Yu XY, Kong CZ. The role of zinc transporter ZIP4 in prostate carcinoma. Urol Oncol 2012; 30: 906-11.

10. Noble PB, Cutts JH. Separation of blood leukocytes by Ficoll gradient. Can Vet J 1967; 8: 110-1.

11. Coban ZD, Avcu F, Ural AU, Akyol M, Güran Ş. Cytotoxic effect of docetaxel on multiple myeloma cell lines (RPMI-8226) as a chemotherapotic agent. Gulhane Med J 2011; 53: 258-63.

12. Jou MY, Hall AG, Philipps AF, Kelleher SL, Lönnerdal B. Tissue-specific alterations in zinc transporter expression in intestine and liver reflect a threshold for homeostatic compensation during dietary zinc deficiency in weanling rats. $\mathbf{J}$ Nutr 2009; 139: 835-41.

13. Jones S, Zhang X, Parsons DW, Lin JC, Leary RJ, Angenendt P, Mankoo P, Carter H, Kamiyama H, Jimeno A, Hong SM, Fu B, Lin MT, Calhoun ES, Kamiyama M, Walter K, Nikolskaya T, Nikolsky Y, Hartigan J, Smith DR, Hidalgo M, Leach SD, Klein AP, Jaffee EM, Goggins M, Maitra A, IacobuzioDonahue C, Eshleman JR, Kern SE, Hruban RH, Karchin R, Papadopoulos N, Parmigiani G, Vogelstein B, Velculescu VE, Kinzler KW. Core signaling pathways in human pancreatic cancers revealed by global genomic analyses. Science 2008; 321: 1801-6.

14. Parikh AA, Liu WB, Fan F, Stoeltzing O, Reinmuth N, Bruns CJ, Bucana CD, Evans DB, Ellis LM. Expression and regulation of the novel vascular endothelial growth factor receptor neuropilin-1 by epidermal growth factor in human pancreatic carcinoma. Cancer 2003; 98: 720-9.

15. Donahue T, Hines OJ. The ZIP4 pathway in pancreatic cancer. Cancer Biol Ther 2010; 9: 243-5.

16. Sher T, Miller KC, Deeb G, Lee K, Chanan-Khan A. Plasma cell leukaemia and other aggressive plasma cell malignancies. Br J Haematol 2010; 150: 418-27.

17. Bladé J, Rosiñol L, Cibeira MT, de Larrea CF. Pathogenesis and progression of monoclonal gammopathy of undetermined significance. Leukemia 2008; 22: 1651-7. 